\title{
College teachers' information literacy training research
}

\author{
Han Zhiying \\ Jilin Huaqiao University of Foreign Languages , Changchun 130117, China, 24921174@qq.com
}

Keywords: Information literacy training; College teachers.

\begin{abstract}
Under the background of education informatization, information technology education plays a revolutionary role. College teachers function as the main force of teaching and scientific research in colleges and universities. Colleges and universities are directly related to the information literacy of teaching quality and talent training quality. This paper provides a feasible strategy from several aspects for college teachers' information literacy training on the basis of scientific analysis of the status quo. The writer looks forward to building the advanced information technology and subject teaching organic integration of modern teachers.
\end{abstract}

\section{Teachers' information literacy status quo at home and abroad}

Information literacy is a kind of basic ability that people need to have under the background of information globalization. College teachers are an important force to promote higher education informationization. Being confronted with the huge changes to the way and teaching, the teachers' information literacy is in great urgency to be raised. In many developed countries, great importance is attached to teachers' information attainments to set up information literacy education committee, and they have taken many ways to improve teachers' information literacy. Many American university multimedia center has dozens of hours per week to help teachers learn education technology, to provides a wealth of online resources for teachers; in Britain the cost of the teachers' information technology training in education accounts for a considerable proportion of the total, and its learn form is varied; by setting the computer center, organization, resource panel for teacher training, Germany help teachers improve information literacy. China Is becoming more and more attentive to the cultivation of teachers' information literacy, the ministry of education "development plan of education informatization decade (2011-2020)" explicitly pointed out that it is necessary to improve university teachers' information literacy and improve teachers' information technology application level. But for a long time, in the field of higher education in China, the cultivation of information literacy is more for students, and teachers in colleges and universities don't have high awareness of information literacy. Current research shows that: in the field of higher education teachers' idea are still obsolete, and they lack information consciousness, do not have the corresponding ability of information technology, so in information technology and course they failed to solve many problems like teaching effective fusion and so on. Level of university teachers' information literacy development is not optimistic in our country, affected the development of the information society to a certain extent. And it is urgent to improve teachers' information literacy as a whole.

\section{Investigation and analysis of college teachers' information literacy}

To know the objective situation of teachers in colleges and universities information literacy, the author together the team selected each of the national key universities, ordinary undergraduate course colleges and universities, and private universities, took the situation in the form of a questionnaire. The survey covers different ages, different titles, and different positions of teachers. The team sent a total of 300 questionnaires, and 284 valid questionnaires were taken back, and the following data statistics are based on the research of valid questionnaires.

Analysis of survey data interpretation is as follows: 


\subsection{Teacher's information consciousness}

Information consciousness is a major aspect of information literacy first. To check how a teacher information literacy is, the first thing is to see its real problems. If we want to solve the problems by using information technology, it means we have the consciousness of teachers' information acquisition. Questionnaire survey:

\begin{tabular}{|l|l|}
\hline $\begin{array}{l}\text { A. Teachers who think the information technology in teaching is essential and can speed up } \\
\text { the progress of the teaching reform }\end{array}$ \\
\hline $\begin{array}{l}\text { B. Teachers who think teachers' information literacy has a greater effect on the } \\
\text { teaching effect }\end{array}$ \\
\hline $\begin{array}{l}\text { C. Teachers who often use a variety of auxiliary teaching of } \\
\text { information technology }\end{array}$ \\
\hline $\begin{array}{l}\text { D. Teachers who are willing to have training through face-to-face or online } \\
\text { courses in information technology }\end{array}$ \\
\hline
\end{tabular}

The investigation result shows that in 2015, teachers' information consciousness had significantly improved compared with indefinite results in a few years ago. With the advancement of education informatization, information technology has brought the revolutionary change for the education teaching. the teachers have generally realized that information technology application level is closely related to the subject teaching effect, the information consciousness has been greatly improved.

\subsection{Teachers' information ability}

Information ability refers the ability of using information knowledge, technology and tools, the ability to solve the problem. It includes the information of basic concepts and principles of understanding and mastering of knowledge, the collection of information resources and management, selection and use of information technology and its tools, the design of the information processing ability. Questionnaire survey:

\begin{tabular}{|l|l|}
\hline $\begin{array}{l}\text { E. Teachers who can make information retrieval accurately and efficiently } \\
\text { and access to useful information }\end{array}$ \\
$\begin{array}{l}\text { F. Teachers who are good at using the information technology } \\
\text { and can achieve good teaching effect }\end{array}$ \\
$\begin{array}{l}\text { G. Teachers who can independently complete Micro class and } \\
\text { class courseware to meet the teaching requirements }\end{array}$ \\
$\begin{array}{l}\text { H. Teachers who often interact with students in } \\
\text { the network }\end{array}$ \\
\hline
\end{tabular}

Survey found that although teachers' information consciousness is on the rise, but there are still barriers in consciousness transformation process, specific teaching activities to the teachers' overall information ability is generally not high, it needs to be promoted. Teachers' information ability is an important guarantee of modern teaching. College teachers should be able to use information technology to build a suitable for their own education teaching information system.

\subsection{Teachers' information ethics}

The rapid development of information age in various fields has brought great conveniences, but also lead to personal information privacy leaks, the infringement of intellectual property rights, illegal network information transmission, network intrusion, and many other problems. As a college teacher the use of information technology to solve the problems of the practical teaching process must strictly abide by the information ethics and information moral accomplishment of self-improvement.

Questionnaire survey: 


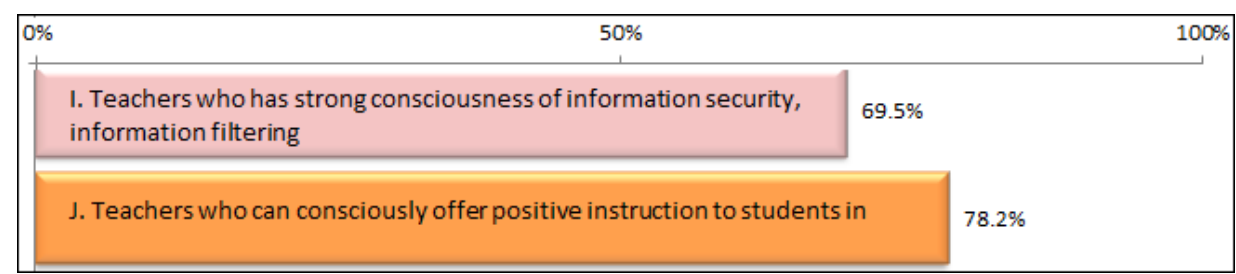

In face of the vast amounts of information, teachers should be able to judge, consciously resist and eliminate spam, harmful information, the interference of unhealthy thoughts and erosion, and can guide students stick to the correct values and morals.

\section{The research and practice of university teachers' information literacy training}

\subsection{The departments of colleges and universities should joint classification, the hierarchical training teachers' information literacy}

Training is a very important and necessary way to improve the teachers' information literacy. Colleges and universities should pay attention to systematic training to improve teachers' level to use computer and network and information technology. However, there exist great differences in the large number of university teachers' group in age, professional degrees, the levels of information technology. In order to achieve the ideal training effect, we should build a reasonable training mode. Information technology center, teacher training center, office, library and other departments shall jointly formulate long-term plan of teachers' information technology training.

First of all, teachers could be divided into information technology teachers group and other disciplines two categories. Information technology teachers determines its own knowledge system and teaching task in the advantage position in the education informatization camp, they grasp the current advanced information technology, network technology, understand the new trends of modern society development. Should take advantage of information technology teachers' professional, let its take part in the training of high-level, shall be borne by them again for other subjects teachers training task, to play a leading and exemplary role, thus promote the teachers' information literacy.

In addition, training for teachers can be separated by simple mechanical age, job title, professional, according to the demand for information technology, master degree and the teachers' professional teachers to scientific division. The information technology application level test can be taken, the cultivation of information literacy investigation to determine the teacher's level and the level of training. In the training process, in line with both teachers' personal development and career development needs of dual goal, teachers can choose the training content, to ensure the training flexible and effective.

\subsection{Make full use of network teaching model for teachers' information literacy training}

In addition to face-to-face training in a planned way, all the functional departments of colleges and universities should make full use of network resources for teachers' information literacy training. Network course is interactive, sharing, open, collaborative and autonomy, the basic characteristics of broke the limitations of time and space, become an important way of teacher training. MOOC is network technology in recent years and the latest achievements of higher education development integration, it speeds up the internationalization of education, the teachers can use MOOC platform for domestic and foreign most advanced information technology curriculum resources, broaden its information in the field of vision. Except for the MOOC platform and network learning community, We Chat public class, network class, online classroom and other forms of online learning for teachers to choose, the teacher must learn to use a variety of network resource independent inquiry learning, collaborative learning, knowledge management, this is the teacher is a kind of ways to cultivate information literacy. 


\section{3 better the system of university teachers' information technology evaluation incentive}

In order to guarantee the effect of the teachers' information literacy training, the functional departments of colleges and universities should arrange personnel to formulate scientific and reasonable training plan, to carry out the training work, and to supervise training quality audit, establish long-term guarantee mechanism. by Setting the university teachers' information literacy standards, and strengthening the information technology training, setting teachers teaching achievement prizes at the declaration in the future, will be of great help. At the same time, developing teachers' potential, motivating teachers to improve themselves to fully mobilize the teachers in the teaching process using advanced information technology. Schools can develop the micro class game, courseware, network curriculum design competition and other kinds of information competition to promote teachers' information technology. In the information technology teaching competition, teachers teams are encouraged to avoid fight alone, it is helpful for teachers to communicate new technology, the teachers can also innovate constantly, with modern technology to illuminate setting of the teaching contents, thus enables the team continuously explore consciousness.

\subsection{Writing information technology reference materials for the teachers}

At present most domestic published information technology teaching materials are in view of the students, it is difficult to meet the demand of the professional teachers' information technology application ability. Due to the different disciplines and specialties in various colleges and universities, the teachers' demand for information technology learning is different. The schools can organize information technology teachers to compile information technology training tutorial or reference materials. Such materials can be used in the selection of the school as professional typical teaching contents, to meet the teaching requirements. Also the tutorial preparation can be taken in the framework of action this tutorial and reference materials for the teachers are more targeted, so the learning effect will be better.

\section{Conclusion}

This paper analyses the present situation of information literacy, college teachers in the teachers' information literacy training of effective strategies. Its research results play a significant role in promoting university teachers' information literacy and education informatization development. And it is forecast by group members in the province professional committee of communication the computer common course teaching in college and universities, making the results more universally convincing.

\section{Acknowledgement}

This is Jilin province twelfth five-year education scientific planning project of university teachers information literacy promotion strategy research and practice achievements. Project ID: GH150575

\section{References}

[1] Decade education informatization development plan (2011-2020). The ministry of education, in March 2012

[2] Michael liu, teachers' information literacy skills [M]. Journal of northeast normal university press, September 2010

[3] JiXueWu, university teachers' information literacy training strategy research [J]. Journal of information science. In May 2012 
[4] Member state pavilion, ya-qing li. MOOC environment improve university teachers' information literacy strategies [J]. Chinese medicine books intelligence magazine. In February 2015 